\title{
Hepatic mRNA expression of acid labile subunit and deiodinase 1 differs between cows selected for high versus low concentrations of insulin-like growth factor 1 in late pregnancy
}

\author{
M. Piechotta, ${ }^{* 1}$ K. Kedves, ${ }^{*}$ M. Gil Araujo,† A. Hoeflich, $\ddagger$ F. Metzger, $§$ M. Heppelmann, ${ }^{*}$ A. Muscher-Banse,\# \\ C. Wrenzycki, ${ }^{\star 2}$ C. Pfarrer,II H. J. Schuberth, П M. Hoedemaker, ${ }^{*}$ H. Bollwein, ${ }^{* 3}$ and M. Kaske* \\ *University of Veterinary Medicine, Clinic for Cattle, Bischofsholer Damm 15, 30173 Hannover, Germany \\ †University of Zulia, Faculty of Veterinary Science, Department of Animal Biology, Maracaibo, Zulia 44011, Venezuela \\ ‡Leibniz Institute for Farm Animal Biology, Mouse Genetics, Wilhelm-Stahl-Allee 2, 18196 Dummerstorf, Germany \\ $\S F$. Hoffmann-La Roche Ltd., CNS Pharma Research \& Early Development, Basel 4070, Switzerland \\ \#Department of Physiology, \\ IIDepartment of Anatomy, and \\ IIImmunology Unit, University of Veterinary Medicine, Bischofsholer Damm 15, 30173 Hannover, Germany
}

\section{ABSTRACT}

The somatotropic axis is a key metabolic pathway during transition from late pregnancy to early lactation in dairy cows. The first objective of this study was to determine the feasibility of selecting cows with persistent differences in total insulin-like growth factor 1 (IGF-1) concentration by taking only a single antepartum blood sample. The second objective was to elucidate the underlying causes of differences in peripheral IGF-1 concentrations throughout late pregnancy and whether hormonal axes also differed in dairy cows with low versus high IGF-1. Twenty clinically healthy Holstein Friesian cows were chosen based on their plasma IGF-1 concentration at 244 to $254 \mathrm{~d}$ after artificial insemination (AI) and other selection criteria (health status, body condition score, number of lactations). These cows were selected from a large-scale farm, transported to the clinic, and monitored daily from 261 to $275 \mathrm{~d}$ after AI. The concentrations of IGF1 , growth hormone, IGF binding proteins 2,3 , and 4 , insulin, cortisol, thyroid hormones, progesterone, and estradiol were measured. Ultimately, 7 IGF-1-low and 7 IGF-1-high cows were statistically analyzed. Additionally, a liver biopsy was taken on d $270 \pm 1$ after AI for analysis of gene expression of somatotropic family members, liver deiodinase 1, and suppressor of cytokine signaling-2. It was possible to select cows with different IGF-1 concentrations based upon only 1 blood sample

Received November 3, 2012.

Accepted March 6, 2013.

${ }^{1}$ Corresponding author: marion.piechotta@tiho-hannover.de

${ }^{2}$ Current address: Clinic for Obstetrics, Gynecology and Andrology of Large and Small Animals, Faculty of Veterinary Medicine, JustusLiebig-University, Frankfurter Strasse 106, 35392 Giessen, Germany.

${ }^{3}$ Current address: Clinic of Reproductive Medicine, VetsuisseFaculty University of Zurich, Winterthurerstr. 260, CH-8057 Zürich, Switzerland. collected in late pregnancy. Concentrations of IGF-1 in IGF-1-low versus IGF-1-high animals ( $\mathrm{n}=7$ each) remained significantly different between groups from the day of selection of the animals until d 275 after AI. Second, the differences in total plasma IGF-1 concentration between experimental groups may be attributed to differences in hepatic production of acid labile subunit. The ability of IGFBP-3 to bind IGF-1 declined before calving in all cows. Furthermore, in addition to decreased mRNA expression of growth hormone receptor $1 \mathrm{~A}$ and IGF-1 relative to calving, serum binding capacities for IGF-1 also decreased. Insulin-like growth factor binding protein $4 \mathrm{mRNA}$ expression was higher in cows with low IGF-1 concentrations; this binding protein inhibits IGF-1 action at the tissue level and therefore may reduce IGF-1 bioavailability. Finally, other endocrine end points (e.g., insulin and thyroid hormones) differed between the 2 groups.

Key words: dairy cattle, pregnancy, insulin-like growth factor, growth hormone

\section{INTRODUCTION}

During late pregnancy, the somatotropic axis is particularly involved in the major adaptive mechanisms that initiate during the dry-off period and facilitate the metabolic transition from late pregnancy to early lactation in dairy cows. This endocrine axis consists primarily of the neuropeptides growth hormone releasing hormone and somatostatin, which regulate the pattern of growth hormone $(\mathbf{G H})$ release and the production of IGF, among others, in the liver (Lucy, 2008). Additionally, the respective receptors for IGF (IGF-1R and IGF-2R), binding proteins for IGF (IGFBP) and $\mathrm{GH}$ itself are involved in the complex regulation of this intermediary metabolism pathway that governs energy metabolism via a multilevel hormonal system (Breier, 1999). 
PIECHOTTA ET AL.

Table 1. Food content on the farm during the study period (from day of selection)

\begin{tabular}{lcccccc}
\hline Content & $\begin{array}{c}\mathrm{DM} \\
(\mathrm{kg})\end{array}$ & $\begin{array}{c}\mathrm{NE}_{\mathrm{L}} \\
(\mathrm{MJ} / \mathrm{kg} \text { per } \mathrm{t})\end{array}$ & $\begin{array}{c}\text { Crude ash } \\
(\mathrm{g} / \mathrm{kg} \text { per } \mathrm{t})\end{array}$ & $\begin{array}{c}\mathrm{OM} \\
(\mathrm{g} / \mathrm{kg} \text { per t })\end{array}$ & $\begin{array}{c}\mathrm{CP} \\
(\mathrm{g} / \mathrm{kg} \text { per t })\end{array}$ & $\begin{array}{c}\text { Crude fiber } \\
(\mathrm{g} / \mathrm{kg} \text { per t })\end{array}$ \\
\hline Soybean meal & 0.7 & 8.7 & 67 & 933 & 510 & 67 \\
Red fescue straw & 3.4 & 3.8 & 69 & 931 & 59 & 392 \\
Rye straw & 1.3 & 3.3 & 58 & 942 & 37 & 472 \\
Corn silage & 1.4 & 6.6 & 45 & 955 & 108 & 182 \\
Grass silage & 4.5 & 4.7 & 125 & 875 & 160 & 236 \\
Total ratio & 11.4 & 4.7 & 96 & 904 & 128 & 291 \\
\hline
\end{tabular}

During the transition from late pregnancy to early lactation in dairy cattle, the liver becomes refractory to GH. In that regard, hepatic growth hormone receptor promoter (GHR1A) mRNA and the GH-binding capacities of liver $\mathrm{GH}$ receptors declined during this period (Vicini et al., 1991; Radcliff et al., 2003a). Total IGF-1 blood concentrations also decreased concurrently, starting approximately $3 \mathrm{wk}$ before calving (Vicini et al., 1991; Radcliff et al., 2003a,b; Gross et al., 2011). In addition to the decrease in hepatic IGF-1 production, which was indicated by the decline in peripheral blood IGF-1 concentration together with the reduction in IGF-1 mRNA production by the liver, IGFBP-3 mRNA also decreased between 3 wk antepartum and the first week postpartum (Gross et al., 2011).

It was previously reported that the antepartum blood levels of total IGF-1 appeared to differ between individual dairy cows (Kawashima et al., 2007). However, neither the underlying cause of these differences nor the cause of the reduction in hepatic GHR1A mRNA expression is clearly understood.

Although the somatotropic axis is referred to as one of the main endocrine axes with a pivotal role during the transition period, several hormones (e.g., insulin, prolactin, ghrelin, glucocorticoids, thyroid hormones, estrogens, and progesterone) control the initiation and maintenance of lactation (Breier, 1999); moreover, interactions between the GH-IGF-1 axis and other hormones are well known. For example, reproductive steroids enhance the sensitivity of the somatotropic axis (Whitlock et al., 2008), and thyroid hormones are also involved in lipid and carbohydrate metabolism (Gross et al., 2011).

The aims of this study were to identify dairy cows with persistently low and high IGF-1 concentrations during late pregnancy, based on a single blood sample collected in the early dry period, and to characterize the endocrine parameters, in particular the somatotropic axis, and metabolic key parameters of those cows for metabolic adaptation.

\section{MATERIALS AND METHODS}

\section{Cows and Selection Criteria}

The present study was performed in accordance with the German legislation on animal welfare (Lower Sax- ony Federal State Office for Consumer Protection 279 and Food Safety, AZ 33.12-42502-04-09/1696). Pluriparous German Holstein Friesian cows in the second to third lactation that had already dried off and were from a large-scale dairy farm (1,100 cows) in Wöpel, Lower Saxony, Germany, were used in this study. On this farm, the dairy cows were housed year-round in a freestall barn with rubber mats. They were fed automatically by a band-conveyor system with a TMR (Table 1) twice daily and were provided with a mineral supply (Panto- Mineral R 66, Hamburger Leistungsfutter GmbH, Hamburg, Germany). Cows had free access to water.

Cows at 240 to $254 \mathrm{~d}$ after AI (which established pregnancy) were clinically examined on the farm (5-25 animals at each farm visit). The clinical examination included assessment of posture, locomotion, rectal temperature, auscultation of heart, lung, and the rumen, and general demeanor. Blood samples were collected (coccygeal vessels) from all clinically healthy cows. An aliquot $(3 \mathrm{~mL})$ of blood was immediately subjected to an in vitro reaction to assess immunoglobulin status, as a rapid estimation of overall health (Sandholm, 1974). Cows with a positive test result in $\leq 3$ min were excluded from further analyses. Additional blood samples were taken in EDTA-containing tubes and serum tubes from animals with a negative glutaraldehyde test. The EDTA samples were centrifuged $(2,000 \times g)$ on the farm within 30 min after blood sampling, and the plasma was stored on ice until subsequent analysis. Serum was harvested by centrifugation $(2,000 \times g)$ after incubating the samples for 30 to $60 \mathrm{~min}$ at room temperature, then stored at $-20^{\circ} \mathrm{C}$ until further analyses.

Plasma IGF-1 concentrations were measured $1 \mathrm{~d}$ after sampling. Based on their total IGF-1 concentration, cows were divided in groups with either low or high antepartum IGF-1 concentrations. The threshold for IGF-1 was chosen based on a previous survey of cows from the same farm (unpublished data) in which 126 blood samples were taken from clinically healthy pluriparous cows at 230 to $260 \mathrm{~d}$ after $\mathrm{AI}$ (median = $248 \mathrm{~d}$ ). The median IGF-1 concentration of this survey was $140 \mathrm{ng} / \mathrm{mL}$. In the present study, the intention was to create 2 groups of cows with maximal differences in IGF-1 concentrations based on the previously de- 
Table 2. Real-time PCR primers for genes of interest in liver biopsy specimens of late-pregnant cows obtained on d $271 \pm 1$ after AI

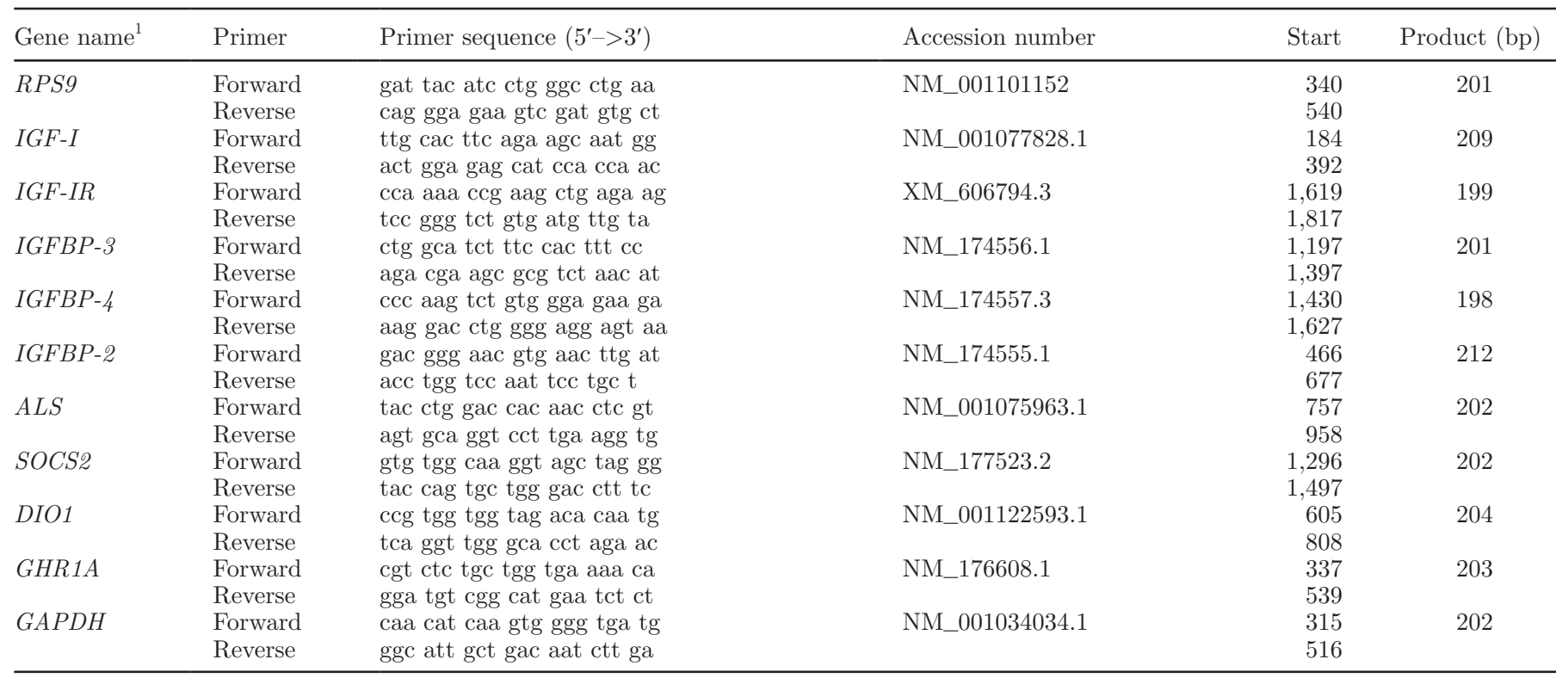

${ }^{1} R P S 9=$ ribosomal protein S9; IGF-IR = IGF-I receptor; IGFBP = IGF binding protein; $A L S=$ acid labile subunit; $S O C S=$ suppressor of cytokine signaling; $D I O=$ deiodinase; $G H R 1 A=$ growth hormone receptor $1 \mathrm{~A}$.

termined threshold. For logistical reasons, 2 cows at maximum were selected and were then transported at 1 wk after selection on the farm (d 261 after AI) to the Clinic for Cattle between January 2009 and March 2011. In the Clinic, the cows were housed in tiestalls with straw bedding. Cows were fed a diet based on ad libitum access to hay and $6 \mathrm{~kg}$ of corn silage with $1 \mathrm{~kg}$ of concentrate (18\% CP, St.Mv.18 III Pell.; ForFarmers Bela GmbH, Vechta, Germany) twice daily. Water and mineralized salt lick were available ad libitum.

\section{Blood and Liver Tissue Sampling}

From d 261 to 275, blood samples were collected once daily in the morning ( $0800 \mathrm{~h} \pm 30 \mathrm{~min})$ from the coccygeal vein into serum tubes and tubes containing potassium-EDTA as an anticoagulant (Sarstedt, Nümbrecht, Germany). The EDTA-plasma (for hormone analyses) and serum samples were centrifuged at room temperature $(2,000 \times g$ for $15 \mathrm{~min})$ within $30 \mathrm{~min}$. Both samples were then frozen and stored at $-20^{\circ} \mathrm{C}$ until analyzed for hormones, binding proteins, and metabolites.

The liver biopsies were done with the assistance of ultrasonographic imaging and local anesthesia $(10 \mathrm{~mL}$ Procasel 2\%, Selectavet, Weyarn-Holzolling, Germany; subcutaneous and intercostal intramuscular) on d 271 \pm 1 as described by Sigl et al. (2012) to determine mRNA levels for specific genes (Table 2). The biopsy specimens $(30 \mathrm{mg})$ were immediately transferred into sterile Eppendorf cups that were frozen in liquid nitro- gen and stored at $-80^{\circ} \mathrm{C}$ until mRNA extraction and PCR analysis.

\section{Hormone and Metabolite Measurements}

$\boldsymbol{I G F - 1}$ and $\boldsymbol{G H}$. Separation of IGF-1 from its binding proteins was performed using an acid-ethanol extraction procedure and total plasma IGF-1 concentration was determined using an IGF-1-coated tube immunoradiometric assay (DSL-5600, Diagnostic Systems Laboratories Inc., Webster, TX). The intra- and interassay CV were 3.5 and $8.5 \%$, respectively.

Bovine GH concentration was determined using an ELISA as previously described (Roh et al., 1997; Kawashima et al., 2007) with the following modifications: a rabbit antibody targeted against ovine GH (antiovine GH-3, 1:20 prediluted, AFP-0802210, from A. F. Parlow, National Hormone and Peptide Program, National Institute of Diabetes and Digestive and Kidney Diseases, Torrance, CA) was diluted 1:10 (final dilution 1:200) and added to all wells of a 96-well microplate that had been previously coated with anti-rabbit $\gamma$-globulin antiserum (gift from D. Schams, Technical University Munich, Weihenstephan, Germany). After incubating for $24 \mathrm{~h}$ at room temperature and decanting the antibody solution, $100 \mu \mathrm{L}$ of $1 \%$ chicken serum diluted in assay buffer was added to each well. A standard solution $(15 \mu \mathrm{L} ; 0.78-100 \mathrm{ng} / \mathrm{mL}$, bovine $\mathrm{GH}$, AFP-9984C, obtained from the National Hormone and Peptide Program, NIDDK, and Dr. Parlow) was dissolved in the assay buffer, controls or plasma samples 
were added, and the plate was then incubated for $24 \mathrm{~h}$ at room temperature. After washing the plate, biotinlabeled GH was added to all wells and then incubated for $3 \mathrm{~h}$ at room temperature. Streptavidin-horseradish peroxidase solution (Sigma Aldrich, St. Louis, MO) was added and incubated for 15 min. After washing, the substrate (containing Tetramethylbenzidine, Sigma Aldrich) was pipetted and after a 10-min incubation the reaction was stopped by adding sulfuric acid $(2 \mathrm{M}$; Sigma Aldrich), the optical density was measured (450 $\mathrm{nm}$ ), and concentrations were calculated using Magellan software and cubic spline modus was used (Magellan 3.11, Dortmund, Germany). Intra- and interassay CV were $9.8 \%$ and $12.6 \%$, respectively. The lowest detection limit for $\mathrm{GH}$ was $2.0 \mathrm{ng} / \mathrm{mL}$.

Thyroxine and Triiodothyronine. Serum thyroxine $\left(\mathbf{T}_{4}\right)$ and triiodothyronine $\left(\mathbf{T}_{3}\right)$ concentrations were determined using competitive chemiluminescence immunoassays (Thyroxin LKCT5 and LKT35, respectively; Immulite 1000 System, Siemens Diagnostics, Eschborn, Germany). The intra-assay CV was 4.4 to $10.8 \%$ for $\mathrm{T}_{4}$ and 7.0 to $13.2 \%$ for $\mathrm{T}_{3}$.

Insulin, Cortisol, Progesterone, and 17 $\boldsymbol{\beta}$-Estradiol. Plasma insulin was measured using an RIA (DSL-1600, Diagnostic Systems Laboratories Inc., Webster, TX). The lowest detection limit for insulin was $2 \mu \mathrm{U} / \mathrm{mL}$. The intra-assay $\mathrm{CV}$ was $6.3 \%$, and the interassay CV was $8.8 \%$. The serum cortisol concentration was measured using an automated competitive chemiluminescence immunoassay (LKCO1, Immulite 1000 System, Siemens Diagnostics). The intra-assay CV was 5.8 to $8.8 \%$, and the analytical sensitivity was 0.2 $\mathrm{ng} / \mathrm{mL}$. The assay has the following cross-reactivities: $49 \%$ prednisolone, $23 \%$ methylprednisolone, $8.6 \%$ corticosterone, and $5.9 \%$ prednisone.

Serum progesterone concentration was determined using a coat-a-count RIA according to the manufacturer's instructions (Progesterone Coat-a-Count, TKPG1, Siemens Medical Diagnostics, Malvern, PA). The analytical sensitivity was $0.02 \mathrm{ng} / \mathrm{mL}$ and the intra-assay CV was $4.0 \%$. The specificity was $100 \%$ for progesterone with the following cross-reactivities: $9.0 \%$ for $5 \alpha$-pregnan-3,20-dione, $3.4 \%$ for hydroxyprogesterone, $3.2 \%$ for $5 \beta$ - pregnan-3,20-dione, $2.2 \%$ for 11 -deoxycorticosterone, and $0.9 \%$ for corticosterone.

Serum $17 \beta$-estradiol $\left(\mathbf{E}_{\mathbf{2}}\right)$ was quantified using a coata-count RIA according to the manufacturer's instructions (Estradiol Coat-a-Count, TKE21, Siemens Medical Diagnostics). The analytical sensitivity was $8 \mathrm{pg} /$ $\mathrm{mL}$ and the intra-assay CV was $4.3 \%$. The assay had the following cross-reactivities: $10.0 \%$ for estrone, $4.4 \%$ for d-equilenin, and $1.8 \%$ for estrone- $\beta$-d-glucuronide. All other manufacturer-grade compounds showed less than $1 \%$ cross-reactivity.
NEFA and BHBA. Serum concentrations of NEFA were measured using a photometric automatic clinical chemistry analyzer (ABX Pentra 400, Horiba, Montpellier, France); the intra-assay CV was $6.2 \%$. The serum BHBA concentration was determined using spectrophotometric enzymatic analysis (Sigma-Aldrich Diagnostics, Munich, Germany; intra-assay CV $=7.1 \%$ ).

\section{Quantitative Western Ligand Blotting}

Quantitative western ligand blotting analysis of serum IGFBP-2, -3 , and -4 to analyze their concentrations via their binding capacities was performed at 5 time points per animal (244 to 254, 261, 276, 271, and $275 \mathrm{~d}$ after $\mathrm{AI}$ ) and was performed as previously described (Metzger et al., 2011). Briefly, serum samples were diluted 1:3 with phosphate buffer $(\mathrm{pH} 7.4)$ and subsequently $1: 2$ with sample buffer $[62.5 \mathrm{~m} M$ Tris- $\mathrm{HCl}$ (pH 6.8), 2\% (wt/vol) SDS, 10\% (wt/vol) sucrose], boiled ( $5 \mathrm{~min}$ ), and electrophoresed on a $5 \%$ stacking and $12 \%$ separating SDS-polyacrylamide gel. Separated proteins were transferred to a polyvinyl fluoride membrane (Millipore, Schwalbach, Germany). The blots were blocked using $1 \%$ fish gelatin and incubated with $\left[{ }^{125} \mathrm{I}\right] \mathrm{IGF}-2$. Using recombinant human IGFBP-2, -3, and -4 as internal standards on each blot, IGFBP were quantified on a Phosphor-Imager Storm (Molecular Dynamics, Sunnyvale, CA).

\section{RNA Isolation and Real-Time PCR}

Total mRNA $(0.5 \mu \mathrm{g}$ of total RNA was used for the RT-PCR) was extracted using the RNeasy Mini Kit for animal tissue and cells (Qiagen, Mississauga, Canada) with QIAcube (Qiagen) according to the manufacturer's instructions. The quality and integrity of the extracted RNA was assessed using an RNA 6000 nanoassay for an Agilent 2100 Bioanalyzer (Agilent Technologies, Böblingen, Germany), and the RNA relative integrity number was at least $>7.5$. The relative abundance of mRNA in the liver biopsy specimen for the quantitative real-time PCR was measured using a BioRad iQ5 (BioRad, Munich, Germany). The PCR reaction mix contained $10 \mu \mathrm{l}$ of Mesa Green qPCR MasterMix Plus for SYBR Assay (Eurogentec, Cologne, Germany), and $0.2 \mu M$ of each forward and reverse primer (Eurofins MWG Operon, Ebersberg, Germany) for genes of interest (Table 2). The PCR-Cycler (Fa. Biometra, Göttingen, Germany) was programmed using the following protocol: RNA denaturation at $95^{\circ} \mathrm{C}$ for $15 \mathrm{~min}$, followed by 43 cycles of $95^{\circ} \mathrm{C}$ for $15 \mathrm{~s}, 60^{\circ} \mathrm{C}$ for $30 \mathrm{~s}$, and $72^{\circ} \mathrm{C}$ for $30 \mathrm{~s}$ for the amplification phase. Transcripts were visualized using SYBR Green, and a subsequent melting curve for verification of the PCR fragments 
initiated at $55^{\circ} \mathrm{C}$, and the temperature was increased by $0.5^{\circ} \mathrm{C}$ every $10 \mathrm{~s}$ up to a final temperature of $95^{\circ} \mathrm{C}$. Relative abundance of mRNA was determined relative to 2 housekeeping genes (ribosomal protein S9, RPS9, and GAPDH; Table 2), which did not differ between cows with low versus high IGF-1 $(P>0.05)$.

\section{Statistics}

The Statistical Analysis System software (version 9.2., SAS Institute Inc., Cary, NC) was used for statistical analyses. The data were first tested for normal distribution using the Kolmogorov-Smirnov test ( $\mathrm{n}>90$; proc univariate normal plot). Then, the data that did not deviate significantly from a normal distribution were presented as the mean $\pm \mathrm{SE}$ or the $\mathrm{LSM} \pm \mathrm{SE}$. Student's $t$-tests were performed to calculate differences in data from the day of selection and also mRNA levels. All other data obtained in the clinic that were not normally distributed were mathematically transformed. Thus, to achieve normal distribution before parametric statistical methods were applied, the following transformations were used: the IGF-1-, $\mathrm{GH}-, \mathrm{T}_{3^{-}}, \mathrm{T}_{4^{-}}, \mathrm{E}_{2^{-}}$, insulin-, and NEFA-values were transformed using the logarithmic natural transformation $[\log \mathrm{X}=\log (\mathrm{X})]$, and BHBA was transformed using the arctangent $[\operatorname{atan} \mathrm{X}=\operatorname{atan}(\sqrt{\mathrm{X}})]$. The IGFBP-3 values were transformed using the square root procedure $[\sqrt{\mathrm{X}}=\sqrt{(\mathrm{X}+1)}]$.

The data collected between d 261 and 275 after AI that were not normally distributed were analyzed using the Kruskal-Wallis test (proc npar1way; SAS Institute Inc.), a nonparametric ANOVA. The normally distributed data were tested for statistically significant differences using repeated measures ANOVA with fixed effects using a mixed model procedure (proc mix and method reml), with the main effects of IGF-1 group $($ IGF-1 low $=0$ and IGF-1 high $=1)$, time (d 261 to 275 after $\mathrm{AI}$ ), and interactions (IGF-1 group $\times$ time). Additionally, the effect of IGF-1 group was tested on IGF-1, GH, $\mathrm{T}_{3}, \mathrm{~T}_{4}, \mathrm{P} 4, \mathrm{E}_{2}$, insulin, NEFA, BHBA, IGFBP-2, IGFBP-3, and IGFBP-4 values (Littell et al., 1998; Littell et al., 2000).

Cortisol concentrations, which were not normally distributed, were analyzed using a non-parametric mixed model procedure (proc mixed method mivque0, SAS Institute Inc.; Littell et al., 1998).

The Bayesian-Schwarz criterion was used to determine the optimal covariance structure matrix (IGF-1, $\mathrm{E}_{2}$, NEFA, IGFBP-3: first-order autoregressive; GH, Cortisol, P4, insulin: compound symmetric; $\mathrm{T}_{3}, \mathrm{~T}_{4}$ and BHBA: variance components; IGFBP-2: first-order autoregressive and random effect; and IGFBP-4: special power) to use in the statistical model. To detect statis- tical differences between variables, orthogonal contrast analysis was performed. The univariate procedure was used to assess the residuals for normality, and the Levene test was used to test for homoscedasticity (SAS Institute Inc.).

The relationships between and within parameters were evaluated using the Spearman and Pearson correlation (proc corr spearman pearson; SAS Institute Inc.). To control for unequal sample size, the homogeneity of variance and random effect were first evaluated using a Brown and Forsythe test (proc gml with option means hovtest $=\mathrm{BF}$ ) and Durbin-Watson test (proc reg options dw; SAS Institute Inc.). For all procedures, the statistical significance was pre-established at $P<$ 0.05 . The $P$-values between $P>0.05$ and $P<0.10$ were considered as statistical tendencies.

\section{RESULTS}

\section{Cows}

In total, 146 cows were subjected to clinical examinations, and 82 blood samples were drawn on the farm for subsequent IGF-1 measurement. Of these cows, 20 clinically healthy Holstein Friesian cows were selected based on their IGF-1 concentration. These cows were selected between d 244 and 254 after AI and were grouped as IGF-1 high ( $\mathrm{n}=10 ; 210 \pm 23 \mathrm{ng} / \mathrm{mL})$ and IGF-1 low $(\mathrm{n}=10 ; 81 \pm 17 \mathrm{ng} / \mathrm{mL})$. The BCS was comparable between both groups $(3.7 \pm 0.1$ vs. $3.7 \pm 0.2$ for IGF-1 high and low, respectively). The average milk yield (305 DIM) of the previous lactation was 8,091 \pm 715 (IGF-1 high) versus $8,336 \pm 874 \mathrm{~kg}$ (IGF-1 low; $P>0.05$ ).

After transport to the clinic, 6 cows were excluded from this study due to either illnesses or spontaneous calvings. Thus, the results of the present study are based on a group size of $n=7$ cows each for IGF-1-high and IGF-1-low groups. These cows remained clinically healthy until d 275 after AI.

\section{Hormone and Metabolite Concentrations}

The total IGF-1 concentration obtained on the day of selection (248 $\pm 3 \mathrm{~d}$ after AI) in the IGF-1-high cows was almost 3 -fold higher than the IGF-1-low cows. At this time, cows with high IGF-1 levels also showed higher insulin concentrations and lower NEFA concentrations than cows with low IGF-1 concentrations, with no significant differences between groups for concentrations of all other hormones tested (Table 3). On d 262, approximately $2 \mathrm{wk}$ after selection of the cows on the dairy farm and subsequent to the transport into the clinic, significant differences between cows with different IGF-1 concentrations obtained throughout the dry 
period were obvious, and these differences remained statistically significant until the end of the study period (d 275 after AI; $P=0.0004$ ).

The decrease in IGF-1 relative to d $275(P=0.0117)$ was similar between the 2 groups (Figure 1 ). The concentration of basal GH measured in the morning did not differ between groups $[\lg 2.6 \pm 0.2$ vs. $\lg 2.5 \pm 0.2$ $\mathrm{ng} / \mathrm{mL}$ for IGF-1 low and high, respectively; (LSM \pm $\mathrm{SE})]$ but was increased relative to d 275 in both groups $(\mathrm{IGF}-1$ low $=\mathrm{d} 260 \mathrm{GH} \lg 2.6 \pm 0.3$ and $\mathrm{d} 275 \lg 3.2 \pm$ $0.3 \mathrm{ng} / \mathrm{mL} ; P<0.001 ;$ IGF-1 high $=$ d $260 \mathrm{GH} \lg 2.3 \pm$ 0.3 and $\mathrm{d} 275 \lg 3.0 \pm 0.2 \mathrm{ng} / \mathrm{mL} ; P<0.001)$.

Total serum $\mathrm{T}_{4}$ concentration was higher in IGF1-low cows compared with their IGF-1-high counterparts $(P<0.0001)$. In both groups, $\mathrm{T}_{4}$ concentrations decreased toward d 275 after AI was observed $(P=$ 0.0051; Figure 2a). Triiodothyronine was also higher in cows with low IGF-1 concentrations $(P<0.0001)$, with no decrease relative to d 275 in either IGF-1-high or IGF-1-low cows (Figure 2b).

The insulin concentration was higher in IGF-1-high cows compared with the IGF-1-low group $(P=0.0151)$. No effect of time or interaction of IGF-1 level with time was detected in either animal group (Figure 3).

Serum cortisol concentrations were comparable between animal groups. Neither significant influence of

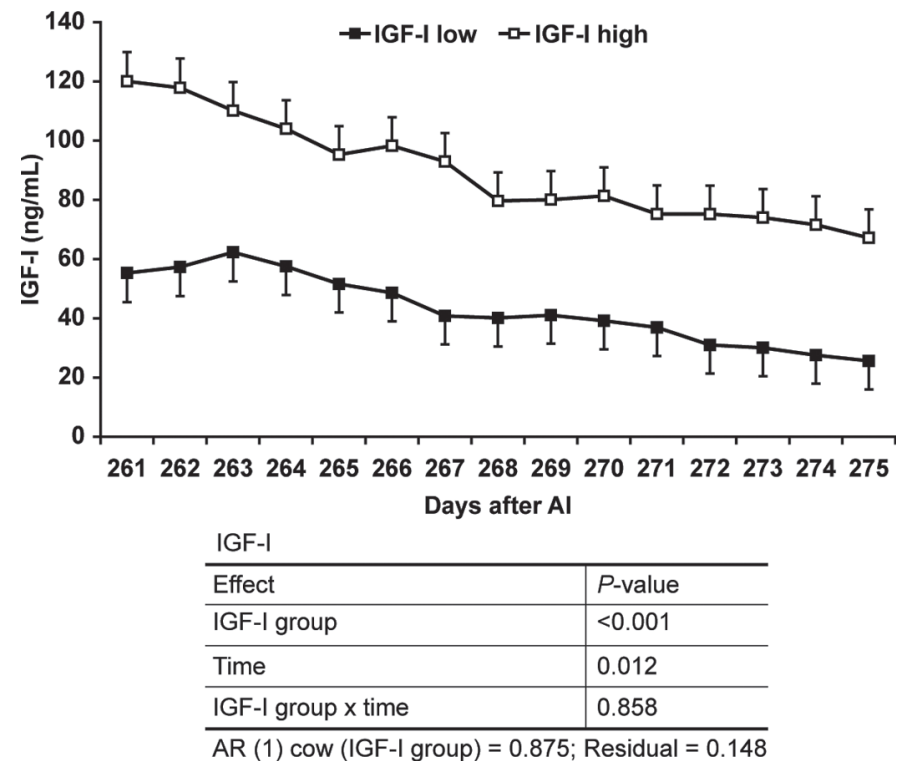

Figure 1. Insulin-like growth factor 1 plasma concentrations (ng/ $\mathrm{mL}$ ) in late-pregnant dairy cows from d 261 to 275 after AI that were selected based on different IGF-1 concentrations at d 244 to 254 after AI (group IGF-1-low vs. IGF-1-high). The data are presented as the mean \pm SE, and significant differences were calculated using the mixed model procedure and are shown in the inset. $\mathrm{AR}(1)=$ autoregressive order 1
Table 3. Differences in various endocrine and metabolic endpoints cortisol, growth hormone $(\mathrm{GH})$, progesterone $\left(\mathrm{P}_{4}\right), 17 \beta$-estradiol $\left(\mathrm{E}_{2}\right)$, insulin, triiodothyronine $\left(\mathrm{T}_{3}\right)$, thyroxine $\left(\mathrm{T}_{4}\right), \mathrm{NEFA}$, and BHBA] with respect to IGF-I group on the day of selection on the farm (d 244 to 254 after $\mathrm{AI})^{1}$

\begin{tabular}{|c|c|c|}
\hline \multirow[b]{2}{*}{ Variable } & \multicolumn{2}{|c|}{ IGF-I group } \\
\hline & $\begin{array}{c}\text { Low } \\
(\mathrm{n}=7)\end{array}$ & $\begin{array}{c}\text { High } \\
(\mathrm{n}=7)\end{array}$ \\
\hline IGF-I (ng/mL) & $84.3 \pm 6.7^{\mathrm{a}}$ & $206.1 \pm 8.0^{\mathrm{b} * *}$ \\
\hline $\mathrm{GH}(\mathrm{ng} / \mathrm{mL})$ & $7.8 \pm 1.0$ & $8.1 \pm 2.0$ \\
\hline $\mathrm{T}_{3}(\mathrm{ng} / \mathrm{dL})$ & $111.5 \pm 9.9$ & $104.0 \pm 6.1$ \\
\hline $\mathrm{T}_{4}(\mu \mathrm{g} / \mathrm{dL})$ & $4.5 \pm 0.3$ & $4.0 \pm 0.3$ \\
\hline Cortisol (ng/dL) & $7.8 \pm 2.2$ & $6.9 \pm 2.7$ \\
\hline $\mathrm{P}_{4}(\mathrm{ng} / \mathrm{mL})$ & $7.5 \pm 0.6$ & $7.9 \pm 0.6$ \\
\hline $\mathrm{E}_{2}(\mathrm{pg} / \mathrm{mL})$ & $24.9 \pm 4.1$ & $34.8 \pm 4.4$ \\
\hline Insulin $(\mu \mathrm{U} / \mathrm{mL})$ & $12.6 \pm 3.0^{\mathrm{a}}$ & $24.3 \pm 3.9^{\mathrm{b} *}$ \\
\hline NEFA (mmol/L) & $157.7 \pm 22.1^{\mathrm{a}}$ & $88.0 \pm 7.7^{\mathrm{b} * *}$ \\
\hline $\mathrm{BHBA}(\mathrm{mmol} / \mathrm{L})$ & $0.6 \pm 0.1$ & $0.7 \pm 0.1$ \\
\hline
\end{tabular}

${ }^{\mathrm{a}, \mathrm{b}}$ Values that differ significantly between columns are indicated using different letters.

${ }^{1}$ Data are displayed as the mean \pm standard error.

$* P<0.05,{ }^{*} * P<0.01$.

time nor IGF-1 level was detected $(P>0.05$; data not shown).

As expected, progesterone concentrations decreased relative to d 275 after AI $(P<0.0001)$, whereas no difference between groups was present. In contrast, $\mathrm{E}_{2}$ levels increased $(P<0.0001)$ relative to d 275 after AI, and again, no differences between groups or interaction between IGF-1 level and time was observed (results not shown).

The NEFA and BHBA concentrations were higher during the study period in the IGF-1-low (logNEFA $6.18 \pm 0.08$ and BHBA $0.700 \pm 0.006 \mathrm{mmol} / \mathrm{L})$ group compared with the IGF-1-high (logNEFA $5.61 \pm 0.08$ and BHBA $0.632 \pm 0.006 \mathrm{mmol} / \mathrm{L} ; P<0.0001)$ group.

\section{Quantitative Western Ligand Blotting}

Serum concentrations of IGFBP-3 [sqrt(IGFBP3)+1] decreased toward d 275 after AI $(P=0.0027)$, with no difference between groups $(P=0.1023$; Figure 4a). Concentrations of IGFBP-2 in the serum increased over time from d 244 to 254 toward d 275 after AI $(P<$ 0.0001; Figure 4b); however, no significant differences between groups or interactions between group and time were observed. Serum concentrations of IGFBP-4 decreased toward d 271 after AI $(P=0.0239$; Figure $4 \mathrm{c})$.

\section{Correlations Between Hormones, Metabolites, and IGF-1 Binding Proteins}

As expected during uncoupling of the somatotropic axis, GH concentrations had moderate negative correlations with IGF-1 concentrations. Furthermore a significant correlation between the thyroid hormones 


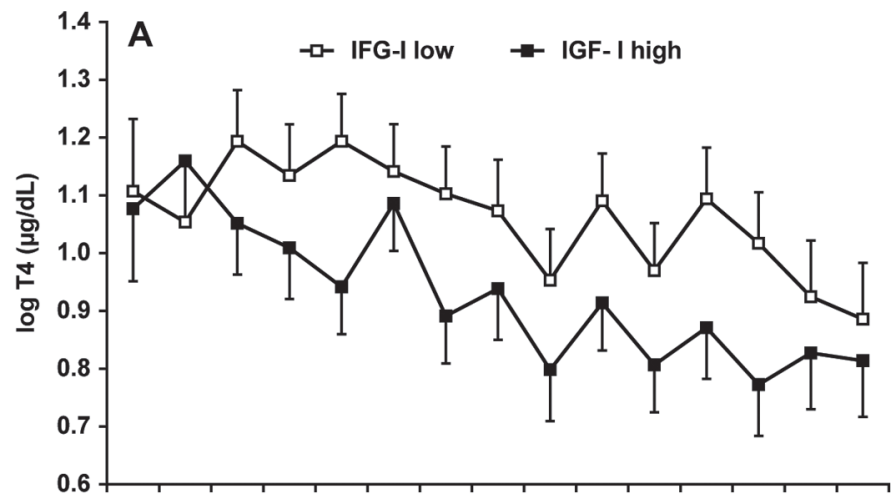

261262263264265266267268269270271272273274275

Days after Al

\begin{tabular}{l|l} 
T4 & \\
\hline Effect & $P$-value \\
\hline IGF-I group & $<0.001$ \\
\hline Time & 0.005 \\
\hline IGF-I group $x$ time & 0.920 \\
\hline Residual cow (IGF-I group) $=0.047$
\end{tabular}

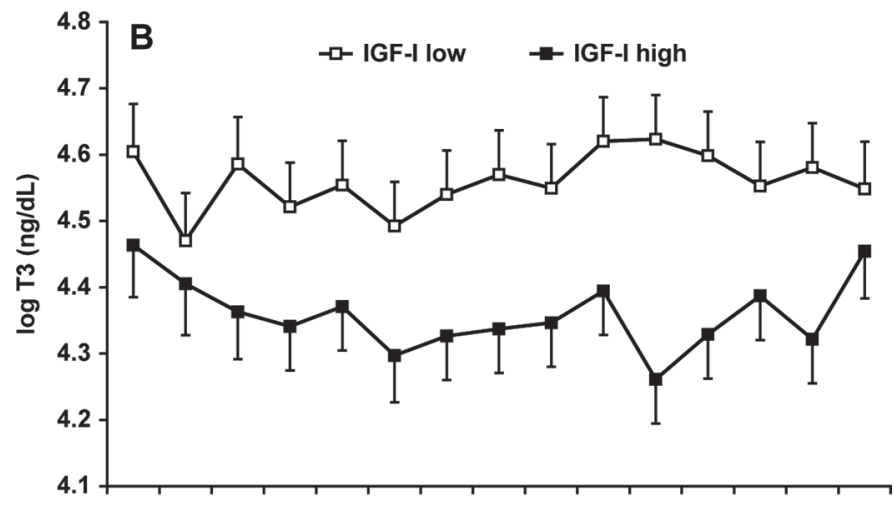

261262263264265266267268269270271272273274275 Days after Al

\begin{tabular}{l|l} 
T3 & \\
\hline Effect & $P$-value \\
\hline IGF-I group & $<0.001$ \\
\hline Time & 0.929 \\
\hline IGF-I group $x$ time & 0.936 \\
\hline \multicolumn{2}{l}{ Residual cow (IGF-I group) $=0.301$}
\end{tabular}

Figure 2. Logarithmic-transformed thyroxin $\left(\mathrm{T}_{4} ; \mu \mathrm{g} / \mathrm{dL}\right)$ and triiododothyronine $\left(\mathrm{T}_{3} ; \mathrm{ng} / \mathrm{mL}\right)$ serum concentrations in late-pregnant dairy cows from d 261 to 275 after AI that were selected based on different IGF-1 concentrations at d 244 to 254 after AI (group IGF-1-low vs. IGF-1-high). The data are presented as the mean $\pm \mathrm{SE}$, and significant differences were calculated using the mixed model procedure and are shown in the inset.

$\mathrm{T}_{3}$ and $\mathrm{T}_{4}$ was noted. Moreover, IGF-1 concentrations were positively correlated with $\mathrm{T}_{4}$ and insulin, whereas a negative correlation between IGF-1 and NEFA and BHBA was observed (Table 4). The total IGF-1 concentrations had a good positive correlation with IGFBP-3 and the sum of all tested binding proteins. Finally, a

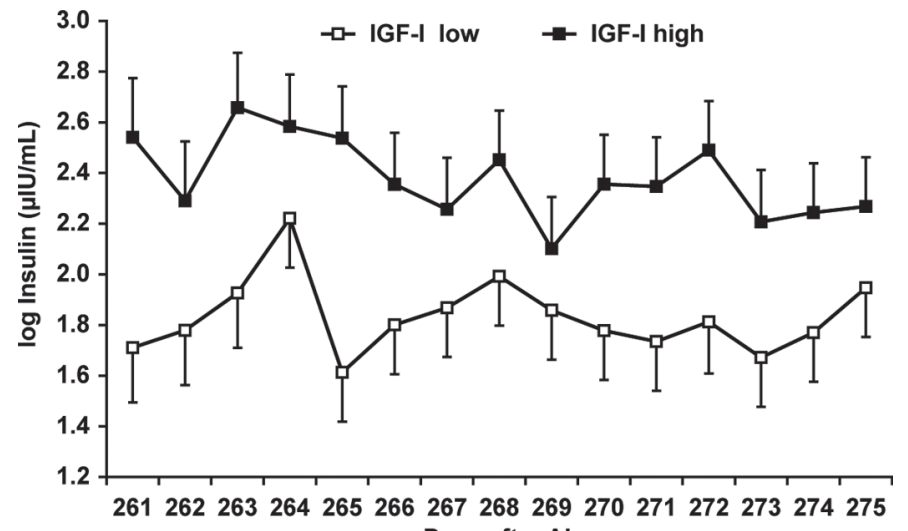

Days after $\mathrm{Al}$

\begin{tabular}{l|l}
\multicolumn{1}{l}{ Insulin } \\
\hline Effect & $P$-value \\
\hline IGF-I group & 0.015 \\
\hline Time & 0.250 \\
\hline IGF-I group $\times$ time & 0.739 \\
\hline AR $(1)$ cow $($ IGF-I group $)=0.119 ;$ & Residual $=0.146$
\end{tabular}

Figure 3. Logarithmic-transformed insulin plasma concentrations $(\mu \mathrm{IU} / \mathrm{mL})$ in late-pregnant dairy cows from d 261 to 275 after AI that were selected based on different IGF-1 concentrations at d 244 to 254 after AI (group IGF-1-low vs. IGF-1-high). The data are presented as the mean $\pm \mathrm{SE}$, and significant differences were calculated using the mixed model procedure and are shown in the inset. $\operatorname{AR}(1)=$ autoregressive order 1 .

negative correlation was noted between total IGF-1 plasma concentration and IGFBP-2 (Table 5).

\section{Hepatic Gene Expression}

The relative abundance of IGF-1 mRNA tended to be lower in the IGF-1-low group when compared with high-IGF-1 cows $(P=0.083)$. However, GHR1A was comparable between IGF-1-low and IGF-1-high cows. No differences in mRNA expression of IGFBP-3 and IGFBP-2 were detected in liver tissue. The IGFBP-4 mRNA expression was higher in cows with low IGF1 concentrations. However, interestingly, acid labile subunit (ALS) mRNA was higher in cows with high IGF-1 concentrations $(P=0.002)$, although low-IGF-1 cows tended $(P=0.1)$ to have higher mRNA expression for SOCS-2 compared with IGF-1-high cows. The deiodinases (DIO) $1 \mathrm{mRNA}$ expression was higher in cows with low antepartum IGF-1; furthermore, these cows also had a high concentration of $\mathrm{T}_{3}(P=0.025$; Figure 5).

\section{DISCUSSION}

The somatotropic axis is involved as the key metabolic pathway facilitating the transition from late pregnancy to early lactation. It was previously reported that cows with low antepartum peripheral IGF-1 

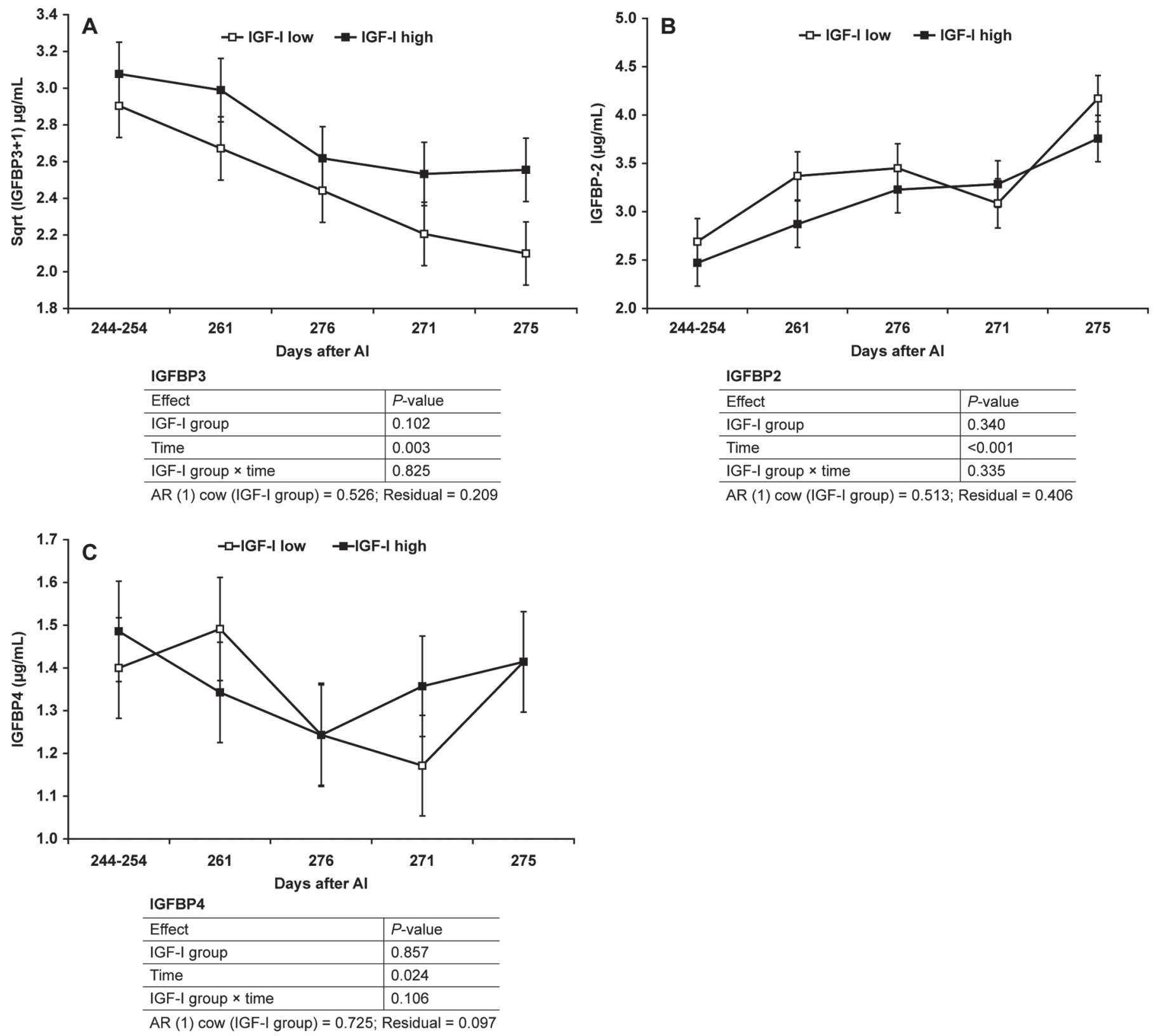

Figure 4. Serum concentrations of IGF-binding proteins (A: IGFBP-3; B: IGFBP-2; C: IGFBP-4) in late-pregnant dairy cows at the day of selection (d 244 to 254 after AI) and at d 261, 276, 171, and 275 after AI. Cows were selected based on different IGF-1 concentrations (group IGF-1-low vs. IGF-1-high). The data are presented as the mean $\pm \mathrm{SE}$ and significant differences were calculated using the mixed model procedure and are displayed in the table next to the figure. $\operatorname{AR}(1)=$ autoregressive order 1.

concentrations developed more frequent metabolic and even infectious diseases in the early postpartum period, suggesting that IGF-1 may be a decisive biomarker (Piechotta et al., 2012). Subsequent to that study, the present investigation aimed to solve 2 central questions. First, is it possible to select cows with persistent differences in total IGF-1 concentration by taking 1 antepartum blood sample? Second, what underlying causes are responsible for the differences in peripheral
IGF-1 concentration throughout late pregnancy, and are other hormonal axes different in IGF-1-low versus IGF-1-high dairy cows?

Cows for this study (IGF-1 high vs. IGF-1 low) were selected based upon 1 blood sample taken between $\mathrm{d}$ 244 and 254 after AI. This time point was chosen based upon a previous study in which differences in IGF-1 concentrations between cows were obvious (Piechotta et al., 2012). Although the cows were then transported 
Table 4. Statistical correlations between cortisol, growth hormone $(\mathrm{GH})$, progesterone $\left(\mathrm{P}_{4}\right), 17 \beta$-estradiol $\left(\mathrm{E}_{2}\right)$, insulin, triiodothyronine $\left(\mathrm{T}_{3}\right)$, thyroxine $\left(\mathrm{T}_{4}\right), \mathrm{NEFA}$, and BHBA in 15 values from 14 cows (values in total: 210)

\begin{tabular}{|c|c|c|c|c|c|c|c|c|c|}
\hline Item & GH & $\mathrm{T}_{3}$ & $\mathrm{~T}_{4}$ & Cortisol & $\mathrm{P}_{4}$ & $\mathrm{E}_{2}$ & Insulin & NEFA & BHBA \\
\hline $\mathrm{GH}$ & & 0.08 & $-0.23^{*}$ & -0.02 & $-0.31^{*}$ & $0.29^{*}$ & $-0.28^{*}$ & 0.10 & 0.11 \\
\hline Cortisol & & & & & $0.20^{*}$ & 0.07 & -0.02 & $0.17^{*}$ & 0.009 \\
\hline $\mathrm{P}_{4}$ & & & & & & $-0.39^{*}$ & $0.17^{*}$ & 0.05 & 0.02 \\
\hline $\mathrm{E}_{2}$ & & & & & & & -0.21 & $0.46^{*}$ & $0.37^{*}$ \\
\hline
\end{tabular}

to another environment (farm versus clinic) and were, therefore, housed (free cubicle stall vs. tiestalls) and fed differently, the distinct differences between IGF1-high versus IGF-1-low cows remained evident $2 \mathrm{wk}$ after selection (d 261 after AI). The 2 groups showed a highly significant difference in total IGF-1 concentration throughout the experimental period until d 275 after AI.

The underlying threshold for IGF-1 grouping was based on a previous survey of the farm (unpublished data) in which the mean IGF-1 concentration was 140 $\mathrm{ng} / \mathrm{mL}$. This IGF-1 concentration was comparable to another study in which the mean concentration of IGF1 was $131.5 \mathrm{ng} / \mathrm{mL}$ at 244 to $254 \mathrm{~d}$ after $\mathrm{AI}$ and where cows with lower IGF-1 concentrations had more postpartum production diseases (Piechotta et al., 2012).

Several parameters have been reported to affect peripheral IGF-1 concentration; these factors were taken into consideration for the present study. Because this study aimed to select cows with possible differences in their metabolic adaptive responses, the following factors, known to influence total IGF-1 concentrations, were excluded. (1) As plasma IGF-1 concentrations are higher in primiparous cows compared with pluriparous cows (Wathes et al., 2007), only pluriparous cows in their second to third lactation were used in this study. (2) The length of the dry period appears to affect IGF-1; cows with short dry periods (5 wk) show higher IGF-1 concentrations than cows with long dry-period management systems (Pezeshki et al., 2007). Thus, all cows in this study were selected from 1 dairy farm and had a similar 8-wk dry period. (3) Genetic selection for high milk yield is accompanied by a prolonged postpartum reduction in IGF-1 (Weber et al., 2007). Moreover, cows with high milk yields have lower postpartum IGF1 concentrations (Taylor et al., 2004). Thus, we selected cows during the dry period that had comparable milk yields in the previous lactation. (4) The length of the photoperiod, as a confounding variable for IGF-1 (Dahl et al., 1997), was minimized by randomly selecting cows with high and low IGF-1 concentrations over an entire year, even when this approach was more predetermined by the study design.

We speculate that the cows with low antepartum IGF-1 levels were less able to cope with the metabolic adjustment to the high energy demands of late pregnancy irrespective of feed intake. In that regard, some cows have great capacity to cope, even with feed restriction during the transition period, and others do not (Doepel et al., 2002). Different metabolic adaptions in IGF-1-low versus IGF-1-high cows were also manifested by higher NEFA and BHBA levels in IGF1-low animals, which are already known as markers of impaired adaption or simple enhanced lipomobilization that provide substrates for hepatic energy production.

The second question of the present study was to characterize the somatotropic axis in IGF-1-high cows and IGF-1-low cows in more detail. Insulin-like growth factor 1 is produced in the liver following the binding of GH to the GHR, which is a G-coupled surface recep-

Table 5. Statistical correlations between IGF and individual IGF binding proteins (IGFBP-3, IGFBP-2, and IGFBP-4) and the sum of all 3 binding proteins ( $\Sigma$ IGFBP) and all 5 time points in $\mathrm{n}=14$ animals $(70$ values in total)

\begin{tabular}{lccccc}
\hline Item & IGFBP-2 & IGFBP-3 & IGFBP-4 & \multicolumn{1}{c}{$\Sigma$ IGFBP } & \multicolumn{1}{c}{ Day } \\
\hline IGFI-I & $-0.58^{*}$ & $0.51^{*}$ & 0.25 & $0.35^{*}$ & $-0.55^{*}$ \\
IGFBP-2 & & -0.09 & -0.16 & 0.18 & $0.46^{*}$ \\
IGFBP-3 & & -0.19 & $0.93^{*}$ & $-0.43^{*}$ \\
IGFBP-4 & & & -0.1 & -0.15 \\
$\Sigma$ IGFBP & & & & $-0.3^{*}$ \\
\hline$* P<0.05$ & & & &
\end{tabular}

$* P<0.05$. 

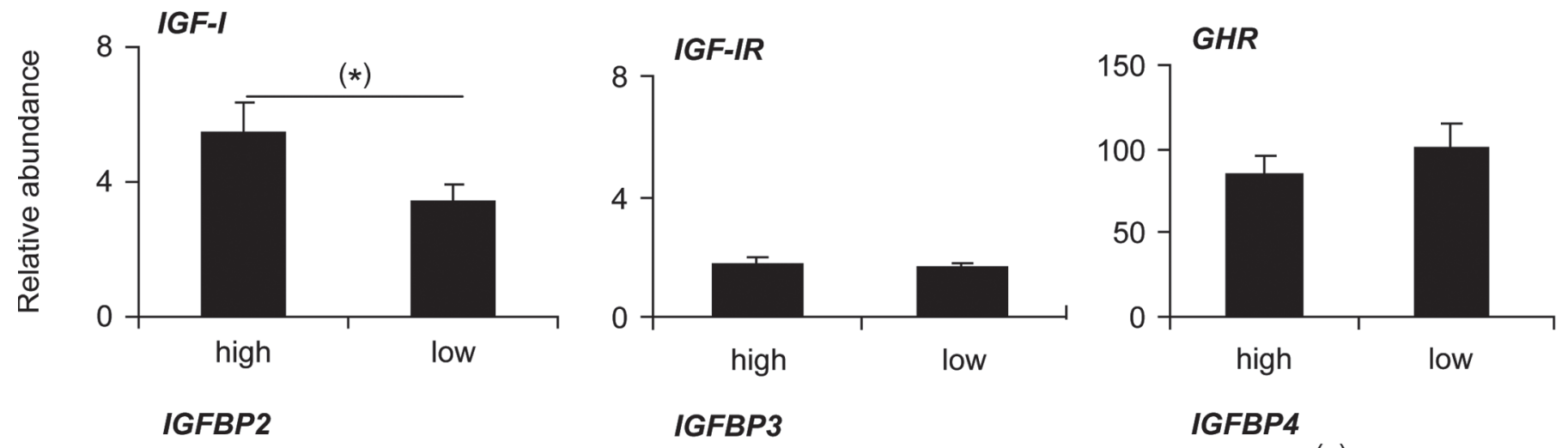

IGFBP2
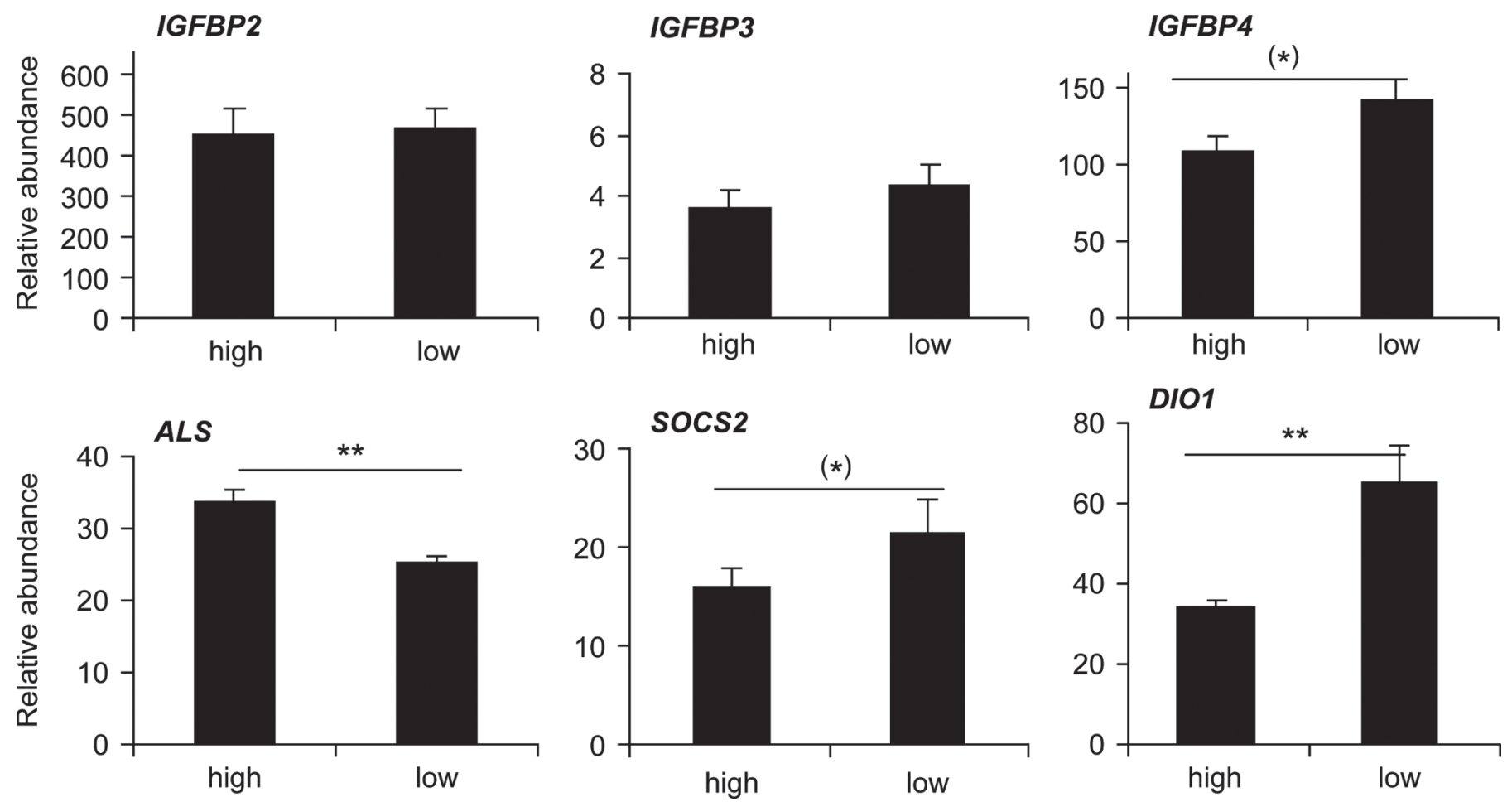

Figure 5. Relative abundance of mRNA expression in liver tissue biopsies that were sampled on $\mathrm{d} 271 \pm 1$. The data are expressed as the mean \pm SE. Significantly different data are indicated as ${ }^{* *} P<0.01$ and $\left({ }^{*}\right) P<0.1$ (tending toward significance).

tor. Following Jak-Stat5-mediated intracellular signal transduction, IGF-1 mRNA is produced and the IGF-1 protein is subsequently released, which itself is bound to at least 7 specific IGFBP (Denley et al., 2005). In dairy cows, the GH-IGF-1 axis uncouples during the transition period to facilitate the transfer of nutrients to the mammary gland for the onset of lactation, and moreover, enables high GH concentrations because $\mathrm{GH}$ is the most important galactopoietic hormone in cattle (Lucy et al., 2001). In agreement with previous reports, during the antepartum period, IGF-1 concentrations decreased comparably in both groups in our study with a concurrent increase in GH (Kawashima et al., 2007). Unexpectedly, GH concentrations and also hepatic GHR1A transcripts were comparable be- tween IGF-1-high and IGF-1-low animals, although, IGF-1 mRNA tended to be higher in cows with high IGF-1 concentrations. That GH concentrations were not significantly different may have been due, at least in part, to once daily measurement. Nocturnal pulses (and accompanying frequency and amplitude) may be more important for IGF-1 production in the liver than the basal concentration measured in the morning. In that regard, acute stress or critical illness in humans (which also leads to an uncoupling of the somatotropic axis) caused an altered profile of GH secretion. This alteration in $\mathrm{GH}$ release is described as a secondary event caused by reduced negative feedback inhibition by IGF-1 (Van den Berghe, 2000). Because the liver may already be refractory to GH in late-pregnant dairy 
cows (Lucy et al., 2001), it is unlikely that either GH or GHR primarily triggered the differences in total IGF1 concentrations in either animal group of our study. Perhaps postreceptor regulation was impaired; in that regard, Winkelman et al. (2008) proposed suppressors of cytokine signaling (SOCS) as potential negative regulators of GHR signaling and reported that SOCS-2 increased in the liver of postpartum dairy cows. In this study, higher hepatic SOCS-2 mRNA expression was observed, as was higher SOCS-2 mRNA expression in cows with lower IGF-1. Sampling was limited, and only mRNA levels were investigated (only 1 liver biopsy on d 271), therefore further studies are required to clarify the mechanism underlying GHR downregulation and postreceptor signaling. Moreover, the GHR protein should also be taken into consideration.

The mRNA amount of ALS was higher in cows with high total IGF-1 concentrations, as ALS is known as a binding protein complexing together with IGFBP-3 IGF-1 in high concentrations (Denley et al., 2005). Unfortunately, ALS protein was not measured in blood, and the assumption that high levels of ALS complexes with IGF-1 and IGFBP-3 and induces higher total IGF-1 remains speculative at this point. Regardless, data from both groups clearly demonstrated that the binding capacity of IGFBP-3, one of the major binding proteins responsible for increasing the half-life of IGF1, decreased significantly between d 244 to 254 and 275. Similarly, in pregnant women and rats increasing protease activity cleaved IGFBP-3 and released more free IGF-1 (Bang and Fielder, 1997; Wu et al., 1999).

Cows with severe negative energy balance have also been shown to exhibit reduced hepatic expression of transcripts encoding IGF-1R, IGF-2R, IGF-1, IGFBP-3, -4, -5, and -6, ALS, and GH (total GHR and $1 \mathrm{~A}$ variant), whereas the expression of IGFBP-2 was elevated (Lucy et al., 2001; Fenwick et al., 2008). In addition, undernutrition is known to trigger an upregulation of IGFBP-2 (Renaville et al., 2002) and a decrease in GHR, IGF-1, and IGFBP-3. In contrast to these findings, IGFBP-2 mRNA expression was comparable between both IGF-1 groups. This finding may be explained by the smaller difference in energy balance on d 270 or 271 compared with the work of Fenwick et al. (2008). The effect of metabolic changes on IGFBP-2 is also substantiated by results from this study because IGFBP-2 binding capacity increased significantly toward calving in both IGF-1-high and IGF-1-low cows in parallel with known changes in metabolism during this time. Similarly, in a previous study (Gross et al., 2011) liver mRNA expression of IGFBP-2 was higher early in postpartum compared with 3 wk antepartum. Furthermore, IGFBP-2 expression may be triggered by low insulin concentrations (Fenwick et al., 2008).
In contrast to other previous studies, we determined not only mRNA expression in the liver but also the biological binding capacity in serum of this binding protein, and the results show clearly that the biological binding capacity increased toward to calving. Furthermore, IGFBP-4 mRNA expression was higher in cows with low IGF-1 concentrations. This binding protein is known to inhibit IGF-1 action at the tissue level and may, therefore, also negatively affect IGF-1 bioavailability.

In addition to the somatotropic axis, it was also our intention to identify potential differences in other hormonal axes. For example, the hypothalamus-pituitarythyroid hormone axis is a further endocrine pathway that aids in the transition of metabolism toward catabolism or even anabolism (Kessel et al., 2008). The thyroid gland produces $\mathrm{T}_{4}$ as an inactive prohormone and peripheral DIO deiodinate this molecule to the active form, $\mathrm{T}_{3}$, and reverses $\mathrm{T}_{3}$. Cows with lower IGF-1 concentrations had higher blood concentrations of both $\mathrm{T}_{4}$ and $\mathrm{T}_{3}$. Liver tissue DIO-1 levels regulate circulating $\mathrm{T}_{3}$ and reverse $\mathrm{T}_{3}$ concentrations; consistent with this association, DIO-1 expression in the liver was higher in cows with low IGF-1 and high serum $\mathrm{T}_{3}$ concentrations. This would have been clarified if reverse $\mathrm{T}_{3}$, a circulating landmark for deiodinase activity (Pezzi et al., 2003), had been measured. Moreover, the secretion of a thyrotropin-releasing hormone or thyroid stimulating hormone could be changed and a thyroid stimulating hormone-mediated thyroid hormone release could lead to an increased production of $\mathrm{T}_{3}$ by the thyroid gland itself. The exact reason for enhanced $\mathrm{T}_{3}$ production in cows with low IGF-1 concentrations in late pregnancy needs to be determined in more detail.

In addition to differences within the somatotropic axis in cows selected based on total IGF-1 concentration in late pregnancy, carbohydrate and lipid metabolism was also affected by the selection criteria IGF-1 concentration. Insulin plasma concentrations were higher in cows with high IGF-1 concentrations on the day of selection (d 244 to 254 after AI) and remained high. Plasma insulin was already discussed as a sensitive signal of metabolism and also as factor causing the GHR downregulation in early pregnancy. It was shown that infusion of insulin restores the GHR expression in the liver; however, that was done during hyperinsulinemic euglycemic clamps in which the insulin concentrations are not physiologically high, which may not be relevant for the physiological condition in dairy cows during transition (Butler et al., 2003). Moreover, serum concentrations of NEFA, which are an indicator of negative energy balance or lipomobilization or inadequate energy intake, were higher in cows with low IGF-1 concentrations. Those IGF-1-low cows already 
displayed a higher ketone body concentration, as previously described in cows with metabolic stress (Kessel et al., 2008). In contrast to our study, Kessel et al. (2008) allocated animals based on their BHBA concentration and reported that IGF-1 concentrations differed (van Dorland et al., 2009). However, these findings raise the question of whether the uncoupling of the GH-IGF-1 axis is the endocrine pathway that guides metabolism toward negative energy balance or whether this axis is only a secondary metabolic level.

\section{CONCLUSIONS}

In conclusion, it was possible to select cows with distinctly different IGF-1 concentrations upon only 1 blood sample collected during late pregnancy. The IGF-1 concentrations in IGF-1-low versus IGF-1-high cows ( $\mathrm{n}=$ 7 each) remained significantly different between groups from selection to d 275 after AI. Second, differences in total plasma IGF-1 concentration between experimental groups may be attributed to differences in hepatic production of ALS. The ability of IGFBP-3 to bind IGF-1 declined before calving in all cows. Therefore, in addition to decreased mRNA expression of GHR1A and IGF-1 relative to calving, serum binding capacities for IGF-1 also decreased. Insulin-like growth factor binding protein 4 mRNA expression was higher in cows with low IGF-1 concentrations; this binding protein inhibits IGF-1 action at the tissue level and, therefore, may also negatively affect IGF-1 bioavailability. Third, other endocrine endpoints (insulin and thyroid hormones) differed between the 2 groups of cows.

\section{ACKNOWLEDGMENTS}

The authors thank Zoetis (Paris, France) for funding this study. Moreover, we thank Martina Baumgarten, Angela Jordan, Katrin Koslowski and Sandra Wilkening (all of University of Veterinary Medicine, Clinic for Cattle, Hannover, Germany) for technical support with hormone analyses and liver mRNA determination.

\section{REFERENCES}

Bang, P., and P. J. Fielder. 1997. Human pregnancy serum contains at least two distinct proteolytic activities with the ability to degrade insulin-like growth factor binding protein-3. Endocrinology 138:3912-3917.

Breier, B. H. 1999. Regulation of protein and energy metabolism by the somatotropic axis. Domest. Anim. Endocrinol. 17:209-218.

Butler, S. T., A. L. Marr, S. H. Pelton, R. P. Radcliff, M. C. Lucy, and W. R. Butler. 2003. Insulin restores GH responsiveness during lactation-induced negative energy balance in dairy cattle: Effects on expression of IGF-1 and GH receptor 1A. J. Endocrinol. 176:205-217.

Dahl, G. E., T. H. Elsasser, A. V. Capuco, R. A. Erdman, and R. R. Peters. 1997. Effects of a long daily photoperiod on milk yield and circulating concentrations of insulin-like growth factor-1. J. Dairy Sci. 80:2784-2789.

Denley, A., L. J. Cosgrove, G. W. Booker, J. C. Wallace, and B. E. Forbes. 2005. Molecular interactions of the IGF system. Cytokine Growth Factor Rev. 16:421-439.

Doepel, L., H. Lapierre, and J. J. Kennelly. 2002. Peripartum performance and metabolism of dairy cows in response to prepartum energy and protein intake. J. Dairy Sci. 85:2315-2334.

Fenwick, M. A., R. Fitzpatrick, D. A. Kenny, M. G. Diskin, J. Patton, and J. J. Murphy. 2008. Interrelationships between negative energy balance (NEB) and IGF regulation in liver of lactating dairy cows. Domest. Anim. Endocrinol. 34:31-44.

Gross, J., H. A. van Dorland, F. J. Schwarz, and R. M. Bruckmaier. 2011. Endocrine changes and liver mRNA abundance of somatotropic axis and insulin system constituents during negative energy balance at different stages of lactation in dairy cows. J. Dairy Sci. 94:3484-3494

Kawashima, C., M. Sakaguchi, T. Suzuki, Y. Sasamoto, Y. Takahashi, and M. Matsui. 2007. Metabolic profiles in ovulatory and anovulatory primiparous dairy cows during the first follicular wave postpartum. J. Reprod. Dev. 53:113-120.

Kessel, S., M. Stroehl, H. H. Meyer, S. Hiss, H. Sauerwein, and F. J. Schwarz. 2008. Individual variability in physiological adaptation to metabolic stress during early lactation in dairy cows kept under equal conditions. J. Anim. Sci. 86:2903-2912.

Littell, R. C., P. R. Henry, and C. B. Ammerman. 1998. Statistical analysis of repeated measures data using SAS procedures. J. Anim. Sci. 76:1216-1231.

Littell, R. C., J. Pendergast, and R. Natarajan. 2000. Modelling covariance structure in the analysis of repeated measures data. Stat. Med. 19:1793-1819.

Lucy, M. C. 2008. Functional differences in the growth hormone and insulin-like growth factor axis in cattle and pigs: Implications for post-partum nutrition and reproduction. Reprod. Domest. Anim. 43:31-39.

Lucy, M. C., H. Jiang, and Y. Kobayashi. 2001. Changes in the somatotrophic axis associated with the initiation of lactation. J. Dairy Sci. 84:113-119.

Metzger, F., W. Sajid, S. Saenger, C. Staudenmaier, C. van der Poel, and B. Sobottka. 2011. Separation of fast from slow anabolism by site-specific pegylation of insulin-like growth factor 1 (IGF-1). J Biol. Chem. 286:19501-19510.

Pezeshki, A., J. Mehrzad, G. R. Ghorbani, H. R. Rahmani, R. J. Collier, and C. Burvenich. 2007. Effects of short dry periods on performance and metabolic status in Holstein dairy cows. J. Dairy Sci. 90:5531-5541.

Pezzi, C., P. A. Accorsi, D. Vigo, N. Govoni, and R. Gaiani. 2003 5 '-Deiodinase activity and circulating thyronines in lactating cows. J. Dairy Sci. 86:152-158.

Piechotta, M., A. K. Sander, J. P. Kastelic, R. Wilde, M. Heppelmann, B. Rudolphi, H. J. Schuberth, H. Bollwein, and M. Kaske. 2012 Short communication: Prepartum plasma insulin-like growth factor-1 concentrations based on day of insemination are lower in cows developing postpartum diseases. J. Dairy Sci. 95:1367-1370.

Radcliff, R. P., B. L. McCormack, B. A. Crooker, and M. C. Lucy. 2003a. Plasma hormones and expression of growth hormone receptor and insulin-like growth factor-1 mRNA in hepatic tissue of periparturient dairy cows. J. Dairy Sci. 86:3920-3926.

Radcliff, R. P., B. L. McCormack, B. A. Crooker, and M. C. Lucy. 2003b. Growth hormone (GH) binding and expression of GH receptor 1A mRNA in hepatic tissue of periparturient dairy cows. J. Dairy Sci. 86:3933-3940.

Renaville, R., M. Hammadi, and D. Portetelle. 2002. Role of the somatotropic axis in the mammalian metabolism. Domest. Anim. Endocrinol. 23:351-360.

Roh, S. G., N. Matsunaga, A. Miyamoto, S. Hidaka, and H. Hidari. 1997. Competitive enzyme immunoassay for bovine growth hormone. Endocr. J. 44:195-198.

Sandholm, M. 1974. A preliminary report of a rapid method for the demonstration of abnormal gammaglobulin levels in bovine whole blood. Res. Vet. Sci. 17:32-35. 
Sigl, T., K. Gellrich, H. H. Meyer, M. Kaske, and S. Wiedemann. 2012. Multiparous cows categorized by milk protein concentration and energy-corrected milk yield during early lactation-Metabolism, productivity and effect of a short-term feed restriction. J. Anim. Physiol. Anim. Nutr. (Berl.) 97:278-296. http://dx.doi. org/10.1111/j.1439-0396.2011.01268.x.

Taylor, V. J., Z. Cheng, P. G. Pushpakumara, D. E. Beever, and D. C. Wathes. 2004. Relationships between the plasma concentrations of insulin-like growth factor-1 in dairy cows and their fertility and milk yield. Vet. Rec. 155:583-588.

Van den Berghe, G. 2000. Novel insights into the neuroendocrinology of critical illness. Eur. J. Endocrinol. 143:1-13.

van Dorland, H. A., S. Richter, I. Morel, M. G. Doherr, N. Castro, and R. M. Bruckmaier. 2009. Variation in hepatic regulation of metabolism during the dry period and in early lactation in dairy cows. J. Dairy Sci. 92:1924-1940.

Vicini, J. L., F. C. Buonomo, J. J. Veenhuizen, M. A. Miller, D. R. Clemmons, and R. J. Collier. 1991. Nutrient balance and stage of lactation affect responses of insulin, insulin-like growth factors I and II, and insulin-like growth factor-binding protein 2 to somatotropin administration in dairy cows. J. Nutr. 121:1656-1664.

Wathes, D. C., Z. Cheng, N. Bourne, V. J. Taylor, M. P. Coffey, and S. Brotherstone. 2007. Differences between primiparous and multipa- rous dairy cows in the inter-relationships between metabolic traits, milk yield and body condition score in the periparturient period. Domest. Anim. Endocrinol. 33:203-225.

Weber, W. J., C. R. Wallace, L. B. Hansen, H. Chester-Jones, and B. A. Crooker. 2007. Effects of genetic selection for milk yield on somatotropin, insulin-like growth factor-1, and placental lactogen in holstein cows. J. Dairy Sci. 90:3314-3325.

Whitlock, B. K., J. A. Daniel, R. R. Wilborn, S. P. Rodning, H. S. Maxwell, and B. P. Steele. 2008. Interaction of estrogen and progesterone on kisspeptin-10-stimulated luteinizing hormone and growth hormone in ovariectomized cows. Neuroendocrinology 88:212-215.

Winkelman, L. A., M. C. Lucy, T. H. Elsasser, J. L. Pate, and C. K. Reynolds. 2008. Short communication: Suppressor of cytokine signaling-2 mRNA increases after parturition in the liver of dairy cows. J. Dairy Sci. 91:1080-1086.

Wu, H. B., C. Y. Lee, and M. M. Rechler. 1999. Proteolysis of insulinlike growth factor binding protein-3 in serum from pregnant, nonpregnant and fetal rats by matrix metalloproteinases and serine proteases. Horm. Metab. Res. 31:186-191. 